\title{
Convergence in Productivity, R\&D Intensity, and Technology Adoption
}

Ana Maria Santacreu, Economist

T here are three ways in which a country can produce more goods and services, that is, achieve economic growth: (i) Employ more workers. (ii) Give workers more tools (capital). Or (iii) use labor and capital more efficiently to increase productivity. Economists have emphasized the role of productivity growth-rather than accumulating more labor or capital-as the main driver of economic growth. In addition, economists believe that innovation is the main engine of productivity growth. Countries that invest more resources into research and development $(\mathrm{R} \& \mathrm{D})$ expand the technological frontier and grow (Romer, 1990). Yet, in a cross section of developed countries, the correlation between research intensity (a rough measure of innovation) and economic growth is not very strong, probably because countries can also grow by adopting innovations created elsewhere (Santacreu, 2015).

Innovation and technology transfer
are significant sources of productivity growth.

Innovative activity is concentrated in very few, very rich countries. According to data from the Organisation for Economic Co-operation and Development (OECD), the United States, South Korea, Japan, and Germany account for the majority of global R\&D. These "leaders" are expanding the technology frontier. However, countries farther behind the technology frontier- "followers"-can also grow by importing technology from the leaders.

Several economists have argued that the transfer of technology and knowledge from leader to follower countries is an important source of economic growth for the latter (Rosenberg, 1982), presumably leading to productivity growth. Transfer of knowledge can occur through imported technology (Coe, Helpman, and Hoffmaister, 1997; Keller, 2004; Santacreu, 2015) and/or multinational activity (Burstein and Monge-Naranjo, 2009, and Guadalupe, Kuzmina, and Thomas, 2012), among other channels. Multinational corporations in innovating countries, for example, transfer knowledge to their affiliates or suppliers in other countries.

Therefore, we can think of innovation and technology transfer as two sources of productivity growth. In this essay, I evaluate the role of these two sources of growth in explaining productivity growth and convergence at the industry level for a sample of 19 OECD countries and 10 manufacturing industries between 1999-2007. ${ }^{1}$ To measure domestic R\&D activity within each country, I use total business R\&D personnel (percent of the total population); to measure potential technology transfer, I use the gap in the level of total factor productivity (TFP) between each country in the sample and the United States in the initial period, that is, in $1999 .^{2}$

To test the contributions of each of these factors to domestic productivity growth, for each country $c$ and manufacturing industry $j$ for each period $t$, I regress yearly TFP growth on the country's technology frontier gap and measure of R\&D activity from 1999 to 2007. Higher values of $R \& D(\% \text { labor })_{c, t}^{j}$ indicate countries with greater domestic R\&D spending, while higher values of $\log \left(\frac{T F P_{U S, 1999}^{j}}{T F P_{c, 1999}^{j}}\right)$ indicate countries farther from the technological frontierthose with greater scope for importing technology.

$\Delta \log T F P_{c, t}^{j}=\beta_{0}+\beta_{1} \log \left(\frac{T F P_{U S, 1999}^{j}}{T F P_{c, 1999}^{j}}\right)+\beta_{2} R \& D(\% \text { labor })_{c, t}^{j}+u_{c, t}^{j}$.

The table reports the results. The positive and statistically significant coefficients on the technology transfer variable, $\log \left(\frac{T F P_{U S, 1999}^{j}}{T F P_{c, 1999}^{j}}\right)$, show that technology transfer is a source of productivity growth in manufacturing industries. That is, countries with a lower level of TFP relative to the United States experience faster manufacturing productivity growth. Moreover, the statistically significant positive coefficients on $R \& D(\% \text { labor })_{c, t}^{j}$ show a positive and significant effect of R\&D activity on productivity growth. In other words, countries that invest more in $\mathrm{R} \& \mathrm{D}$ have a larger increase 


\section{Sources of Productivity Growth: R\&D Intensity and Technology Adoption, 1997-2007}

\begin{tabular}{|c|c|c|c|c|}
\hline$\triangle \log T F P_{c, t}^{j}$ & (1) & $(2)$ & (3) & (4) \\
\hline $\log \left(\frac{T F P_{U S, 1999}^{j}}{T F P_{c, 1999}^{j}}\right)$ & $\begin{array}{c}0.019 * \\
(0.007)\end{array}$ & $\begin{array}{c}0.022^{*} \\
(0.009)\end{array}$ & $\begin{array}{c}0.024^{*} \\
(0.010)\end{array}$ & $\begin{array}{r}0.024^{*} \\
(0.009)\end{array}$ \\
\hline$R \& D(\% \text { labor })_{c, t}^{j}$ & $\begin{array}{l}0.020^{* *} \\
(0.007)\end{array}$ & $\begin{array}{l}0.098^{* *} \\
(0.036)\end{array}$ & $\begin{array}{l}0.098^{* *} \\
(0.036)\end{array}$ & $\begin{array}{c}0.068 \\
(0.038)\end{array}$ \\
\hline Country fixed effects & No & Yes & Yes & Yes \\
\hline Industry fixed effects & No & No & Yes & Yes \\
\hline Year fixed effects & No & No & No & Yes \\
\hline Observations & 1,285 & 1,285 & 1,285 & 1,285 \\
\hline$R^{2}$ & 0.011 & 0.027 & 0.034 & 0.062 \\
\hline
\end{tabular}

in productivity. These results are robust to including industry, country, and year fixed effects.

Taken together, the results show that both domestic innovation and technology transfer play a significant role in productivity growth. Given two country-industry pairs with the same productivity gap relative to the United States, the one that invests more in R\&D will have faster productivity growth. For instance, Germany and Finland have the same productivity gap relative to the United States in the "transportation equipment" industry; however, Finland spends more in R\&D for that industry than Germany. As a result, Finland's productivity growth in that industry is larger than Germany's.

\section{Notes}

${ }^{1}$ The countries are Australia, Austria, Belgium, Canada, the Czech Republic, Germany, Denmark, Spain, Finland, France, Great Britain, Hungary, Ireland, Italy, Japan, the Netherlands, Slovenia, Sweden, and the United States.

2 I follow Cameron, Proudman, and Redding (2005), who assess the role of innovation and technology transfer in explaining productivity growth at the industry level in the United Kingdom since 1970.

\section{References}

Burstein, Ariel T. and Monge-Naranjo, Alexander. "Foreign Know-How, Firm Control, and the Income of Developing Countries." Quarterly Journal of Economics, February 2009, 124(1), pp. 149-95; https://doi.org/10.1162/qjec.2009.124.1.149.

Cameron, Gavin; Proudman, James and Redding, Stephen. “Technological Convergence, R\&D, Trade and Productivity Growth." European Economic Review, 2005, 49(3), pp. 775-807; http://econpapers.repec.org/article/ eeeeecrev/v_3a49_3ay_3a2005_3ai_3a3_3ap_3a775-807.htm.

Coe, David; Helpman, Elhanan and Hoffmaister, Alexander. "North-South R\&D Spillovers." Economic Journal, 1997, 107(440), pp. 134-49; http://econpapers.repec.org/article/ ecjeconjl/v 3a107 3ay 3a1997 3ai 3a440 3ap 3a134-49.htm.

Guadalupe, Maria; Kuzmina, Olga and Thomas, Catherine. "Innovation and Foreign Ownership." American Economic Review, December 2012, 102(7), pp. 3594-627; https://www.aeaweb.org/articles?id=10.1257/aer.102.7.3594.

Keller, Wolfgang. "International Technology Diffusion." Journal of Economic Literature, 2004, 42(3), pp. 752-82; http://econpapers.repec.org/article/aeajecli t/v 3a42 3ay 3a2004 3ai 3a3 3ap 3a752-782.htm.

Romer, Paul M. "Endogenous Technological Change." Journal of Political Economy, October 1990, 98(5), pp. 71-102; http://econpapers.repec.org/article/ucpjpolec/v $3 a 98$ 3ay 3a1990 3ai 3a5 3ap 3as71-102.htm.

Rosenberg, Nathan. Inside the Black Box: Technology and Economics. Cambridge, UK: Cambridge University Press, 1982; https://ideas.repec.org/a/eee/jeborg/v6y1985i1p98-100.html.

Santacreu, Ana Maria. "Innovation, Diffusion, and Trade: Theory and Measurement." Journal of Monetary Economics, October 2015, 75, pp. 1-20; https://doi.org/10.1016/j.jmoneco.2015.06.008. 